\title{
THE EFFECT OF BOND CHARACTERISTICS, FINANCIAL PERFORMANCE AND MACRO VARIABLES ON RETURN OF CORPORATE BOND IN THE AGRIBUSINESS SECTOR
}

\author{
Dewi Kusumaningrum ${ }^{* 1}$, Lukytawati Anggraeni**), and Trias Andati***) \\ *) School of Business, IPB University \\ Jl. Raya Pajajaran, Bogor 16151, Indonesia \\ ${ }^{* *}$ Department of Economics, Faculty of Economics and Management, IPB University \\ Jl. Agatis, Campus of IPB Darmaga Bogor 16680, Indonesia \\ ${ }^{* * *)}$ PT. Adhimix Precast Indonesia \\ Jl. Raya Ps. Minggu No. 17 A, Pancoran Jakarta Selatan 12780, Indonesia
}

\begin{abstract}
There are several reasons why companies choose to issue bonds rather than borrowing from banks. Interest paid by companies to bond investors is often lower than the interest rate charged by the bank, but still at least bond issuance from the agricultural sub-sector and chooses to lend to the bank. The purpose of this study is to analyze the influence of bond characteristics, financial performance and macroeconomic return on corporate bonds in the agribusiness sector. This study uses a panel data regression method consisting of 12 bonds with the vulnerable time between 2014-2015 \quarterly. Based on the panel data model shows that the characteristics of bonds (yield to maturity, coupon, rank, and duration), financial performance (CFOS) and macroeconomics (IHSG) have a significant effect on the return of bonds. The Company should consider the amount of bond yield and coupon to be issued and pay attention to financial performance, especially cash flow and capital expenditure (capital expenditure).
\end{abstract}

Keywords: agribusiness sector, bonds, characteristics, performance, macroeconomics

\begin{abstract}
Abstrak: Terdapat beberapa alasan yang membuat perusahaan memilih untuk menerbitkan obligasi dibanding dengan meminjam pada bank. Bunga yang dibayarkan perusahaan kepada investor obligasi sering kali lebih rendah dari tingkat suku bunga yang dibebankan oleh bank, namun masih sedikitnya penerbitan obligasi dari sektor pertanian dan memilih untuk melakukan peminjaman pada bank. Tujuan penelitian ini adalah menganalisis pengaruh karakteristik obligasi, kinerja keuangan dan makroekonomi terhadap return obligasi korporasi pada sektor agribisnis. Penelitian ini menggunakan metode regresi data panel yang terdiri dari 8 obligasi dengan rentan waktu antara tahun 2014-2015 secara triwulan. Berdasarkan model data panel menunjukkan bahwa karakteristik obligasi (yield to maturity, kupon, peringkat dan durasi), kinerja keuangan (CFOS) dan makroekonomi (IHSG) berpengaruh signifikan terhadap return obligasi. Perusahaan harus mempertimbangkan besaran yield dan kupon obligasi yang akan diterbitkan serta memperhatikan kinerja keuangan terutama arus kas dan pengeluaran modal (capital expenditure).
\end{abstract}

Kata kunci: agribisnis, obligasi, karakeristik, kinerja, makroekonomi

\footnotetext{
${ }^{1}$ Corresponding author:

Email: dewikusumaningrum92@yahoo.com
} 


\section{INTRODUCTION}

The capital market is a long-term market in which is a wide range of capital market instruments that are traded. Investors are confronted with a wide range of alternative instruments to be developed and managed in the long term to get appropriate expectations. This investment is made to finance its operations through the issuance of shares and bonds. The bond is financial asset that is traded on stock exchanges. The bond itself is divided into two types, government bond and corporate bond. Corporate bonds are bonds issued by BUMN and private companies. One type of bonds traded in the stock market today is the coupon bond with a fixed interest rate which must be paid periodically during the term of the bond (Astuti, 2003). Along with the development of corporate bonds, if this term learned by sector, the agribusiness sector is one of the sectors that experienced a quite good bond growth. Sectoral growth in corporate bonds can be seen in Table 1.

Table 1 shows that the agribusiness sector is one sector that has quite a lot of enthusiasts and experienced an average of considerable growth in the amount of $13 \%$. Thegribusiness sector includes all activities relating to the handling of agricultural commodities in the comprehensive sense which includes one or all of the chain of production, processing the input and output of production (agro-industry), agriculture, and institutional support the activities. Institutional support activities are all activities that has a function for supporting, serving, and developing activities upstream subsystem, subsystem cultivation and downstream subsystem (Saragih, 1998). Including pulp and paper industry, wood industry, cement and fodder that were in basic industry and chemicals. As well as the food and tobacco industry that had previously been in the consumer goods sector. An enterprise including farming if only raw material that is processed in a factory or a business unit that is a commodity that directly generated from nature without prior processing that changes the basic composition.

The agribusiness sector quiet holds an important role in the national economy which the development of agribusiness in Indonesia as a poverty reduction strategy (Akhmadi et al. 2015). It is because: (1) the expansion of other sectors of the economy is highly dependent on the growth of output in agriculture, both in terms of supply and demand as a source of raw materials for production purposes in other sectors such as manufacturing and trade; (2) the role of agriculture as an important source for the growth of domestic demand for the products of other sectors; (3) as a source of capital for investment in other economic sectors; and (4) as an important source of trade surplus (foreign exchange).

The agribusiness sector is the sector with quite high capital requirements that be able to continue to grow. The capital requirement is obtained from a private capital company, individual private capital, cooperatives, government capital, company lease (leasing companies), credit institutions, capital from domestic and foreign, and the heritage of the bank (Halimah, 1992). One alternative to complete the capital requirements is by issuing bonds. According to Rahardjo (2003), there are three objectives of the company issuing the bonds, the first one is obtaining additional funding that can be more flexible tailored to the needs of the company. The second one is getting a loan with a flexible interest rate. The process of determining the interest rate (coupon) bond is determined based on their financial capabilities and concerning conditions in the banking interest rate. The third one is getting alternative financing through the capital market. Bonds issued by the agriculture sector can be seen in Table 2 .

According to Table 2 is currently in the agribusiness sector that uses bonds as a funding source subsystems dominated in the upstream than the downstream subsystems. On the upstream subsystem dominated by plantation subsector, while the downstream subsystems are sub-sectors and subsectors beverages and food also animal feed. As the data from the number of DER, subsystems upstream discount amount is greater than the ratio of the downstream subsystems. It means that the capital requirements of company's subsystems upstream widely obtained from bank lending. The increase of DER will result in a high financial risk, thus the use of debt the greater the risk the company experienced higher the default risk (Indra, 2006).

Potential credit risk of bonds can be analyzed by the shift in the company's financial performance which can be learned by the shift in cash flow and the company's ability to meet its obligations, to the financial performance analysis of the solvency ratio. In addition, the macro-economic conditions also influence investment performance and condition of the company, which in turn influence the returns to be obtained. Jamillah (2012) stated that variable financial performance, growth and macro-economic effect on bond returns. 
Table 1. Corporate bond growth by sector 2014-2015

\begin{tabular}{lccc}
\hline Sector & \multicolumn{2}{c}{ Outstanding (Billion) } & Growth (\%) \\
\cline { 2 - 3 } & 2014 & 2015 & \\
\hline Agribusiness * & $197,200,038$ & $214,962,270$ & 13.43 \\
Mining & $101,826,546$ & $71,249,561$ & -20.63 \\
Basic Industries and Chemicals & $15,139,309$ & $39,847,101$ & 87.61 \\
Various Industries & $81,894,823$ & $93,427,004$ & 1.32 \\
Consumer goods & 41.35996 million & $42,673,018$ & 10.57 \\
Property, Real estate and construction & $201,235,531$ & $213,217,672$ & 31.28 \\
Finance & $314,222,142$ & $333,729,992$ & 16.95 \\
Trade, Services and Investment & $280,425,278$ & $236,137,512$ & 16.23 \\
\hline
\end{tabular}

Note: * agriculture sector, food and beverages sub-sector, sub-sector of animal feed, pulp and paper, sub-sectors, sub-sectors of wood industries, cement sub-sector, sub-sector of tobacco manufacturers

Source: Data compiled from IDX Statistics 2014-2015

Table 2. Value DER bonds of agribusiness sector

\begin{tabular}{lll}
\hline Subsystem & Company & DER \\
\hline Upstream & PT Sinar Mas Agro Resources and Technology & 1.83 \\
& PT Tunas Baru Lampung Tbk & 2.46 \\
Downstream & PT BW Plantation & 1.84 \\
& PT Indofood Sukser Makmur Tbk & 1.04 \\
& PT Japfa Comfeed Indonesia Tbk & 1.84 \\
& PT Mayora Indah Tbk & 1.47 \\
& PT Nippon Indosari Corporindo & 1.32 \\
& PT Tiga Pilar Sejahtera Food Tbk & 1.13 \\
\hline
\end{tabular}

Previous studies have focused on the characteristics of the bonds, the company and the interest rate as determined by Herlambang (2015) on the banking subsector. Nurfauziah and Setyarini (2004) found that the level of interest rates does not effect on bond yields. Return of bonds previously studied by Fama and French (1993) by the method of time series on corporate bonds. Fabozzi and Modigliani (2009) asserted that the duration is not a measurement of time, but an estimate of the percentage change in the price of bonds to changes in interest rates. As for the agricultural sector bond lack of previous studies. Ziebart and Reiter (1992) in his study obtained results that debt to equity influential and positively related to bond yields. Chatrath et al. (2012), stated that large bond yields are more sensitive to macroeconomic news than the rated bonds. Corner (2011) stated that the performance of corporate bonds over government bonds outperform compared to the level of risk-adjusted.
This study aims to: analyze the influence of the characteristics of the bond; such as a coupon, yield to maturity, duration (maturity) and the rating of the bonds; financial performance; macro-economic conditions; such as inflation, interest rates, and IHSG to return the corporate bonds in agribusiness sector Indonesia.

\section{METHODS}

The data used in this research is secondary data obtained from the relevant institutions in Indonesia. Table 3 is the details of the types and sources of data used in the study. The sampling technique used purposive sampling with criteria: 1) Corporate bonds have been listed on the Stock Exchange and have not yet maturity in the period 2014-2015,2) Pay quarterly coupons in a fixed amount, 3) Bonds does not have a convertible feature, and 4) Financial statements full issuer during the period of observation. Based on these criteria, selected some samples of bonds shown in Table 4 . 
Table 3. Types and sources of data used

\begin{tabular}{lccc}
\hline Variables & Variables & Unit & Data source \\
\hline Return & $\mathrm{Y}$ & Percent & Financial Statements and IDX statistics \\
Yield to Maturity & $\mathrm{X} 1$ & Percent & Financial Statements and IDX statistics \\
Coupon & $\mathrm{X} 2$ & Percent & IDX statistics \\
Due date & $\mathrm{X} 3$ & Year & IDX statistics \\
Rating & $\mathrm{X} 4$ & ordinal & PEFINDO \\
Duration & $\mathrm{X} 5$ & Year & Calculation \\
Debt to Equity Ratio & $\mathrm{X} 6$ & Ratio (times) & Financial statements \\
interest Coverage & $\mathrm{X} 7$ & Ratio (times) & Financial statements \\
Cash Flow to Sufficiency & $\mathrm{X} 8$ & Ratio (times) & Financial statements \\
Interest Rate Bonds & $\mathrm{X} 9$ & Percent & Bank Indonesia \\
Inflation & $\mathrm{X} 10$ & Percent & Bank Indonesia \\
JCI & $\mathrm{X} 11$ & Percent & Bank Indonesia \\
\hline
\end{tabular}

Table 4. Sample Bonds

\begin{tabular}{lll}
\hline Company & Subsector & ID Bonds \\
\hline PT Sinar Mas Agro Resources and Technology & Plant & SMAR01ACN1 \\
& & SMAR01BCN1 \\
PT Tunas Baru Lampung Tbk & Plant & TBLA02 \\
PT BW Plantation & Plant & BWPT01 \\
PT Japfa Comfeed Indonesia Tbk & Animal feed & JPFA01CN1 \\
& & JPFA01CN2 \\
PT Mayora Indah Tbk & Food and Drink & MYOR04 \\
& & SMKMYOR02 \\
PT Nippon Indosari Corporindo & Food and Drink & ROTI01CN1 \\
PT Tiga Pilar Sejahtera Food Tbk & Food and Drink & AISA01 \\
& & SIAISA01 \\
\hline
\end{tabular}

Table 4 is samples that finds the criteria for upstream subsystems are 3 and 4 bond issuers, to downstream subsystems are 5 and 8 bond issuers. Processing and analysis of data in the present study using panel data regression techniques. With research over the 20142015 time period in the quarter. Data were collected panels in cross-section and are followed when a certain period/time series. Cross-section data collected at a certain time, while the time series data collected over time (Nachrowi and Usman, 2006). Data panel models that have been developed from Jamillah (2012) and Rahmi (2016) as follows:

$\mathrm{Y}_{\mathrm{it}}=\alpha+\beta_{1} \mathrm{X}_{1 \mathrm{it}}+\beta_{2} \mathrm{X}_{2 \mathrm{it}}+\beta_{3} \mathrm{X} 3 \mathrm{it}+\beta_{4} \mathrm{X}_{4 \mathrm{it}}+\beta_{5} \mathrm{X}_{5 \mathrm{it}}+\beta_{6} \mathrm{X}_{6 \mathrm{it}}$ $+\beta_{7} X_{7 i t}+\beta_{8} X_{8 i t}+\beta 9 X_{9 i t}+\beta_{10} X_{10 i t}+\beta_{11} X_{11 i t}+\varepsilon$

Description: $\mathrm{i}(\mathrm{n}$ bond); $\mathrm{t}(\mathrm{n}$ the period of observation); $\alpha$ (intercept); $\beta$ (regression coefficient of the independent variable (slope)); Y (return); $\mathrm{X}_{1}\left(\mathrm{YTM}\left(\right.\right.$ percent)); $\mathrm{X}_{2}$
(Coupon (percent)); $\mathrm{X}_{3}$ (Maturities (years)); $\mathrm{X}_{4}$ (Rating (ordinal)); $\mathrm{X}_{5}$ (Duration (years)); $\mathrm{X}_{6}$ (Debt to Equity Ratio (time)); $\mathrm{X}_{7}$ (Interest coverage ratio (times)); $\mathrm{X}_{8}$ (ratio Cash Flow to Sufficiency (time)); $\mathrm{X}_{9}$ (Interest rate (percent)); $\mathrm{X}_{10}$ (Inflation (percent)); $\mathrm{X}_{11}$ (JCI (percent)); $\varepsilon$ (error).

Hypothesis:

$\beta_{3}, \beta_{4}, \beta_{9}, \beta_{11}<0 ; \beta_{1}, \beta_{2}, \beta_{5}, \beta_{6}, \beta_{7}, \beta_{8}, \beta_{10}>0$

Data processing techniques consist of several stages such as 1) doing the classic assumption test including normality test, multicollinearity test, heteroscedasticity test and autocorrelation test. 2) To select the model used in panel data covering common effect, fixed effect and random effect were tested through the chow test and Hausman test to get the best model. The test result data used free of classical assumptions that can be used for further testing and the model chosen is a common 
effect. 3) The panel data regression analysis was done to test the effect of independent variables on the dependent variable. Based on the description of the background research and analysis methods, the framework in this study can be seen in Figure 1.

\section{RESULTS}

\section{Descriptive Data Analysis}

Characteristics of the sample used in this study include number of samples, the average value, maximum value, minimum value and standard deviation for each variable. Results of descriptive statistics dependent and independent variables are presented in Table 5. Based on the results of calculations during the observation period shows that the return of corporate bonds in the Agribusiness sector has a standard deviation of 0.0372 . A small standard deviation shows that there is not a lot of variance in the variable return. The highest return value of bonds owned by PT Mayora by $87 \%$ the price of bonds amounting to 92.9 .

Data yield to maturity (YTM) low of $1.6 \%$ and the highest $16.5 \%$ while the average yield to maturity of $3.14 \%$ with a standard deviation of 0.0256 . Standard deviation value is smaller than the average value YTM show that the absence of fluctuations of YTM is too big in corporate bonds during the quarter year period 20142015.

Coupon on each bond amount is different, the largest coupon bonds that are Islamic bonds, or sharia bonds, issued by PT Mayora Indah Tbk amounting to $39.29 \%$, while the lowest is Islamic bonds issued by PT Tiga Pilar Sejahtera by $2.66 \%$. The average of the coupon of $11 \%$ is the value that still quite large enough to attract investors to invest in the company's agribusiness sector.

The maturity bonds agribusiness sector has a fairly long time. It is seen by a minimum time to maturity is still above 5 years and a maximum maturity period of 7 years. Duration in Table 5 has a standard deviation of 0.71010 , it is the same as the result of YTM has a small standard deviation value which means there is too much variance in the variable duration. Duration has the highest value of 4.8 , the lowest score of 0.2 and the average rating was 1.8. In this study, the majority of bonds have a duration of one year, the mean duration of the condition of the bond is shorter than the period.
The financial performance is seen from Debt to Equity Ratio and solvency (Interest Coverage and Cash Flow to Sufficiency). Each has a standard deviation that is smaller than the value its average, excluding for ratios of IC and CFOS the standard deviation value which is greater than the value its average. It is because a company in a particular quarter are not expending Capex (Capital Expenditure) to purchase or maintain fixed assets as well as an EBIT obtained in subsequent periods is not greater than the previous period. The distribution of the data showed an asymmetrical distribution that can be seen from Skewness value greater than zero.

\section{Testing Model}

The selection of a model obtained from the test results of Chow and Hausman test that showed the best model used is a model common effect. The results of testing the model in this study can be seen in Table 6 .

According to the results of the panel data regression is shown in the table above, four variables significantly influence the return of bonds at $5 \%$ level; namely YTM, coupons, ratings, and rate CFOS. Duration and IHSG have a significant effect on the level of $10 \%$. As for the other variables did not affect the return of bonds in the agribusiness sector.

$\mathrm{R}^{2}$ results of this research is 0.472423 , it is clear that the independent variables can explain the return as much as $47.24 \%$ while the remaining $52.76 \%$ is explained by other factors outside of this model, therefore the model completely unfit for further analysis, because the figure is approaching $50 \%$. A probability value of $\mathrm{F}$-statistic significant effect on the level of 0.000003 , smaller than $\alpha$ of $5 \%$. This means that the majority (at least one) independent variables simultaneously influence the dependent variable, namely the return of the bond agribusiness sector.

\section{Interpretation Model}

\section{YTM influence on return}

The test results showed a variable yield to maturity has a $\mathrm{p}$-value $<\alpha(\alpha=5 \%)$, then reject H0 thus it is consistent with the hypothesis. The negative sign on the coefficient indicates an inverse relationship between the yields to maturity with the return of the bond that is a proxy of bond prices, bond prices decline when the yield to maturity increases, causing the return of bonds 
will decline. This is according to research Herlambang (2015) and Rahmi (2016) which states that the yield to maturity affects negatively the return.

\section{Coupon influence on return}

The coupon has a positive significant effect on return, this agrees with the theory that the positive effect on return coupon. Bond with a higher coupon has a greater cash flow in the initial period so that its value is less sensitive to changes in the discount interest rate. Therefore couponsinfluence on the return because of the high value of the coupons that will give higher returns as well. If the coupon is high enough then bond prices will tend to increase. It is appropriate research Damena et al. (2014) which states that the higher the coupon rate of the bond, the higher the demand for bonds and the rate of the price change or return bonds.
Rank influence on return

This study showed that variables have the rank p-value $<\alpha(\alpha=5 \%)$, then reject H0 then ranked significantly affect the return. Their negative sign on the coefficient shows a negative relationship. Directions negative coefficient reflects that the higher the rank of a bond then the probability of default (default risk) would be small, little default risk which will provide a high return. The lower the bond rating, the fluctuations in bond prices will be higher so that the bonds will be higher risk and returns will also be higher. The results are consistent with the results of research Bhojraj and Sengupta (2003), Crabtree and Maher (2005) which states that there is a negative relationship and significant return bonds. Followed by Surya and Nasher (2011), Hammami and Bahri (2016), bond.

Table 5. Descriptive statistics dependent and independent variables

\begin{tabular}{lccccccccccccc}
\hline & return & YTM & Coupon & Maturity & Ranked & duration & DER & IC & $\begin{array}{c}\text { CFOS } \\
\text { Interest } \\
\text { rate }\end{array}$ & Inflation & IHSG \\
\hline mean & 0.03 & 0.03 & 0.11 & 5.33 & 6.75 & 2.01 & 1.61 & 4.90 & 0.68 & 0.08 & 0.06 & 0.01 \\
median & 0.02 & 0.03 & 0.10 & 5.00 & 7.00 & 2.00 & 1.51 & 2.58 & 0.48 & 0.08 & 0.07 & 0.01 \\
Max & 0.14 & 0.16 & 0.39 & 7.00 & 7.00 & 4.76 & 2.42 & 69.06 & 4.28 & 0.08 & 0.08 & 0.10 \\
Min & -0.11 & 0.01 & 0.03 & 5.00 & 5.00 & 0.22 & 1.05 & -39.47 & 0,00 & 0.08 & 0.03 & -0.07 \\
Std dev. & 0.04 & 0.03 & 0.09 & 0.75 & 0.60 & 0.71 & 0.42 & 13.17 & 0.76 & 0,00 & 0.02 & 0.05 \\
skewness & -0.17 & 2,86 & 2.72 & 1.81 & -2.25 & 0.87 & 0.44 & 6.77 & 2,14 & 2.30 & -0.82 & 0.03 \\
\hline
\end{tabular}

Table 6. Factors affecting return bond of the agribusiness sector

\begin{tabular}{lcccc}
\hline Variable & Coefficient & Std. Error & t-Statistic & Prob. \\
\hline YTM & $-0.799138 * *$ & 0.327181 & -2.442497 & .0171 \\
Coupon & $0.199682 * *$ & 0.086753 & 2.301730 & .0243 \\
Maturity & -0.006573 & 0.004820 & -1.363820 & .1769 \\
Ranked & $-0.009940 * *$ & 0.004442 & -2.237579 & .0284 \\
Duration & $0.011530 *$ & 0.006691 & 1.723296 & .0892 \\
DER & 0.002932 & 0.004759 & 0.616154 & .5398 \\
IC & $5,18 \mathrm{E}-06$ & $6,72 \mathrm{E}-06$ & 0.770676 & .4435 \\
CFOS & $0.007704 * *$ & 0.003238 & 2.379393 & 0.0200 \\
Interest rate & 0.943311 & 3.537651 & 0.266649 & .7905 \\
Inflation & -0.301452 & 0.234976 & -1.282909 & .2037 \\
IHSG & $-0.102103 *$ & 0.059172 & -1.725544 & .0888 \\
$\mathrm{C}$ & 0.021381 & 0.262744 & 0.081377 & .9354 \\
\hline $\mathrm{R}^{2}$ & 0.472423 & Prob (F-statistic) & & 0.000003 \\
\hline Note: & r & & & \\
\hline
\end{tabular}

Note: * significant at the $10 \%$ level; ** Significant at the $5 \%$ level 


\section{Managerial Implications}

At the significant level $\alpha 10 \%$, the variable duration has a positive significant effect on bond returns agribusiness sector, but the direction of the coefficients in this study acyl contrary to allegations which had a negative correlation direction. According to Gebhardt et al. (2005), the duration of a significant effect on returns by way of negative coefficients. The longer the maturity period, the longer the duration of a bond that will have an impact on the risk of maturity. In theory, explained that the bonds have the longest maturity the bond prices increasingly vulnerable to yield, but in the present study coupon bond owned large enough, then the price becomes insensitive to bond yield changes.

\section{CFOS influence on return}

The next independent variable is CFOS which is part of sufficiency ratio of a company, the test results are known $\mathrm{p}$-value $<\alpha(\alpha=5 \%)$, then these variables have a significant influence in the direction of the positive coefficient. Companies that can repay short and longterm debt, long-term, make purchases and pay the interest burden of the greater it will provide greater return to investors. According to Chen et al. (2010), a company that has a high solvency ratio liquidity ratio increasingly rnedah. The higher a company's ability to generate profits, investors expect yields to be higher. The profit can be used by companies to increase investment so that it will boost the company's growth.

\section{JCI influence on return}

Based on test results, the variable JCI has a p-value $<\alpha$ $(\alpha=10 \%)$, then the variable CSPI has an influence on bond returns with a positive coefficient means having a positive relationship. Any increase in JCI will lead to a decline in bond prices so that demand for bonds will also increase, and vice versa if the JCI decline will push prices toward the higher bond so that the demand for bonds also declined. The results are consistent with research Sihombing (2014) which showed that JCI has a significant negative effect return bonds. JCI increase demonstrates the passion of investing in stocks that will affect the level of investment in other products that degrade investigation in bonds.

\section{Issuers}

One alternative source of long-term funding that is with new bond issuance. To be absorbed and the bond market demand by the company must consider the amount of yield and coupon bonds that will be issued. Companies must also consider financial performance, especially cash flow and capital expenditures (CapEx). Cash flows used for the payment of the bond coupon interest, though a bond had a pretty good ranking, but if companies delay the payment of the coupon will lower the reputation of the company that will result in reduced levels of investor confidence.

Characteristics strongly influence the bond coupon rate, nominal bonds and the price of bonds to be issued. Low return showing the capital cost of the bond would be cheaper, but the demand for bonds will decrease from investors that will lead to lower demand for bonds in the capital market. Optimal capital costs need to be considered when the issuer will issue bonds so the cost can be adjusted by the number of funds to be obtained and the number of returns to be received by investors.

\section{Investors}

Investors should consider the growth prospects of issuers that can be seen from CapEx budgeted by the issuer. The cash flows generated by the company should be able to meet the operational needs and capital costs, this is related to collateral for the payment of interest and principal at maturity, so the risk of default is low.

Characteristics of bonds that need to be considered investors are YTM. High returns obtained from the low YTM value. Investor also should choose a bond with good bond ratings. Bonds with good ratings will be desirable so that the bond price will be high. Investors who want to get a rate of return can look at the yield to maturity is low. See the company's financial performance, and investors should not hesitate to buy bonds with a long duration if owned high coupon rate. The decline in bond prices will lead to lower bond returns. 
Regulation

The government also needs to encourage issuers to take advantage of the capital market such as stocks and bonds as a financing alternative that is no longer dependent on the banks, one of which providing an incentive for companies to issue bonds, to encourage companies to implement good corporate governance. Companies that issue bonds must also comply with the regulation No. Kep-86/PM/1996 regarding the disclosure of information should be made public so that investors and bond issuers can find out information about bonds. Financial services authority as the regulator should provide data such as the value of bonds yield to maturity and duration to facilitate investors in investing.

\section{CONCLUSIONS AND RECOMMENDATIONS}

\section{Conclusions}

Characteristicsvariable bonds, the company's financial performance and the macroeconomic variables have an influence on the bond characteristic variable return. namun more significant than other variables, so that the company issuing the bond financing decisions can consider variable bond characteristics compared to the financial performance and macroeconomic variables. Variable characteristics of bonds, financial performance and affect the return is YTM, coupons, ratings, duration and cFos while macroeconomic variables that influence the JCI.

\section{Recommendations}

Future studies could examine the factors that affect bond returns in other sectors to consider the opportunity to invest it.

\section{REFERENCES}

Akhmadi, Siregar H, Hutagaol MP. 2015. Development of agribusiness as a strategy for poverty reduction in rural areas. Journal of Management and Agribusiness 13(3): 240-253.

Astuti S. 2003. Effects of Financial Statements Against Debt Rating (Bond Rating). Empirical Study At Company in Jakarta Stock Exchange. Jakarta: Wahanas.

Bhojraj S, Sengupta P. 2003. Effect of corporate governance on bond ratings and yields: The role of institutional investors and outside directors. The Journal of Business 76(3): 455-475. https:// doi.org/10.1086/344114.

Chatrath A, Miao H, Ramchander S, Villupuram S. 2012. Corporate bonds, macroeconomic news and investor flows. Fixed Income 22(1): 25-39. https://doi.org/10.3905/jfi.2012.22.1.025.

Chen NF, Roll R, Ross SA. 2010. Economic forces and the stock market. The Journal of Business 59(3): 383-403. https://doi.org/10.1086/296344.

Crabtree AD, Maher JJ. 2005. Earnings predictability, bond rating and bond yields. Review of Quantitive Finance and Accounting 25(3): 233-253. https:// doi.org/10.1007/s11156-005-4766-2.

Damena, Herdy, Ervita, Safitri, Aprilia R. 2014. Analysis of the influence of the coupon (interest bonds), maturity and liquidity of the bonds on the rate of change in prices of bonds listed on the Indonesia Stock Exchange. Journal of Management Department STIE MDP 20(3): 1-8.

Fabozzi FJ, Modigliani F. 2009. Capital Markets: Institutions and Instruments. 4th ed. New Jersey: Prentice Hall.

Fama EF, French KR. 1993. Common risk factors in the returns on stocks and bonds. Financial Economics 33(1993): 3-56. https://doi.org/10.1016/0304405X(93)90023-5

Gebhardt WR, Hvidkjaer S, Swaminathan B. 2005. The cross-section of expected corporate bond returns: Betas or characteristics ?. Economic Finance 75(2005): 85-114. https://doi.org/10.1016/j. jfineco.2004.04.002.

Hammami Y, Bahri M. 2016. On the determinants of expected corporate bond returns in Tunis. Research in International Business and Finance 3(8): 224-235. https://doi.org/10.1016/j. ribaf.2016.04.015.

Halimah WK. 1992. Agricultural Finance and Corporate Finance Agribusiness. Jakarta: Gramedia Pustaka Utama.

Herlambang R. 2015. Analysis of the characteristics of bonds against return bonds in the banking sub-sector 2010-2013. Journal of Management Applications 14 (2): 272: 280.

IndraAZ. 2006. Factors affecting financial fundamentals share risk. Journal of Business \& Management 2 (3): 239-256.

Jamillah S. 2012. Analysis of the influence of financial performance, the possibility of investment and 
macro variables to the yield on corporate bonds [thesis]. Bogor Agricultural University in Bogor Nachrowi ND, Usman H. 2006. Popular and Practical Approach Econometrics for Economic and Financial Analysis. Jakarta: Issuing Faculty of Economics, University of Indonesia.

Nurfauziah, Setyarini FA. 2004. Analysis of the factors that affect the yield on corporate bonds (a case study on the banking industry and the financial industry). Journal of Business Strategy 2(9): 241-256. https://doi.org/10.20885/jsb.vol2.iss9. art6.

Raharjo S. 2003. Bonds Investment Guide. Jakarta: Gramedia Pustaka Utama.

Rahmi A. 2016. Analysis of the influence of bond characteristics, characteristics of the company and macroeconomic factors to the return of corporate bonds on the infrastructure sector, utilities and transport [thesis]. Bogor: Institut Pertanian Bogor.

Ross SA, Weterfield RW, BD Jordan, Lim J, Tan R. 2015. Introduction to Corporate Finance. Ed Global
Asia Books to 1. Translators Ratna Saraswati, Editor of Chess Saso. Jakarta: Salemba Four.

Saragih B. 1998. Agribusiness set Thinking: New Paradigm of Agriculture-Based Economic Development. Jakarta: Foundations Mulia Persada Indonesia.

Sari SRK, Bandi. 2010. The related earnings management practices bond ratings. Accounting XIII.Purwokerto National Symposium October 13 to 15 .

Sihombing P. 2014. Determinants of yield curve of government securities (GS) [dissertation]. Bogor: Institut Pertanian Bogor.

Surya BA, Nasher TG. 2011. Analysis of the effect of interest rate (SBI), the exchange rate, the size of the company, debt to equity ratio and bond the yield of corporate bonds in Indonesia. Journal of Technology Management 10 (2): 186-195.

Ziebart DA, Reiter SA. 1992. Bond ratings, bond yields and financial information. Contempory Accounting Research 9(1): 252-282. https://doi. org/10.1111/j.1911-3846.1992.tb00879.x. 